\title{
Ensuring Fiscal Sustainability in G-7 Countries
}

\author{
David Hauner, Daniel Leigh, and \\ Michael Skaarup
}





\title{
IMF Working Paper
}

Fiscal Affairs Department

\section{Ensuring Fiscal Sustainability in G-7 Countries}

\section{Prepared by David Hauner, Daniel Leigh, and Michael Skaarup ${ }^{1}$}

Authorized for distribution by Manmohan S. Kumar

July 2007

\begin{abstract}
This Working Paper should not be reported as representing the views of the IMF. The views expressed in this Working Paper are those of the authors and do not necessarily represent those of the IMF or IMF policy. Working Papers describe research in progress by the authors and are published to elicit comments and to further debate.

Rising longevity, falling fertility rates, and the retirement of the baby boom generation will substantially raise age-related government spending in most advanced and many emerging market countries. This paper assesses the evolution of fiscal sustainability for each of the G-7 countries using two standard primary gap indicators. The estimated fiscal adjustment required to ensure long-run fiscal sustainability is substantial for all G-7 countries. In particular, ensuring fiscal sustainability would require an average improvement in the primary balance of about 4 percentage points of GDP. While the overall adjustment required to achieve long-run fiscal sustainability in G-7 countries is large, there are significant growth benefits to putting public finances on a sustainable footing in the near term versus delayed adjustment.
\end{abstract}

JEL Classification Numbers: D58, E17, E62, H68

Keywords: Fiscal sustainability, aging, general equilibrium models

Author’s E-Mail Address:DHauner@imf.org,DLeigh@imf.org, MSkaarup@imf.org

\footnotetext{
${ }^{1}$ We thank Tamim Bayoumi, Timothy Callen, Daniel Citrin, Charles Collyns, Mark De Broeck, Manmohan S. Kumar, Alessandro Zanello, Bob Matthias Traa, James Morsink, and Werner Schule for many helpful comments and suggestions.
} 


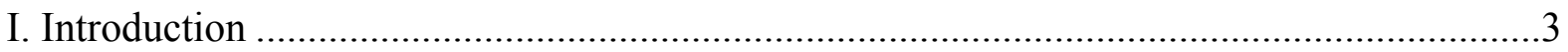

II. Evolution of Age-Related Expenditures .................................................................

III. Evaluating Changes in Fiscal Sustainability .........................................................6

A. Indicators for Assessing Fiscal Sustainability ............................................

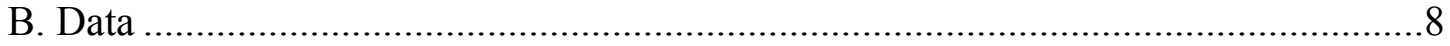

C. Estimation Results: Primary Gaps............................................................... 10

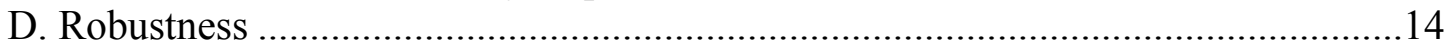

IV. Delayed Versus Immediate Fiscal Adjustment: Macroeconomic Effects .......................17

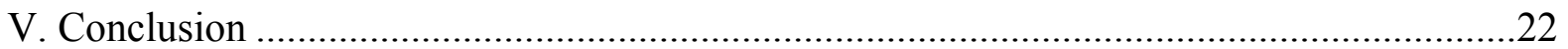

Tables

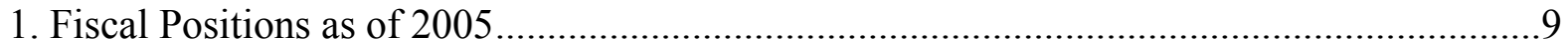

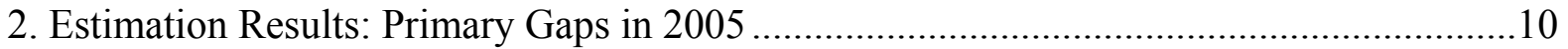

3. Estimated Fiscal Impact of Recent Pension and Health Care Reforms ..............................13

4. Debt-Target Primary Gap for Alternative Target Years:

60 Percent Debt-to-GDP Ratio Target ................................................................... 15

5. Impact of Changing the Debt Target on Debt-Target Primary Gap ................................15

6. Impact of Higher Aging Costs on Intertemporal Primary Gap..........................................16

7. Effect on Intertemporal Primary Gap of Reducing the Growth-Adjusted Interest Rate by 1 Percentage Point

Figures

1. Projected Cumulative Growth in Old-Age Population and Increase in Age-Related Spending Relative to 2005 .5

2. Closing the Primary Gap: Gross Debt Dynamics, 2005-2080 ........................................ 7

3. Rolling Estimates of the Intertemporal Primary Gap, 2001-05 ....................................12

4. Public Debt, Restoring Sustainability Immediately and with a Delay..............................19

5. Primary Fiscal Balance: Restoring Sustainability Immediately and with a Delay .............20

6. Real GDP: Restoring Sustainability Immediately and with a Delay ..............................21

7. Debt Dynamics and Aging Costs in the Stylized Example.............................................25

Appendices

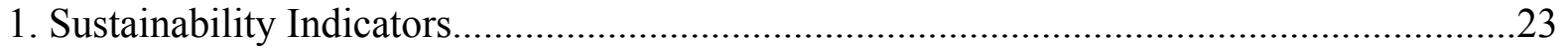

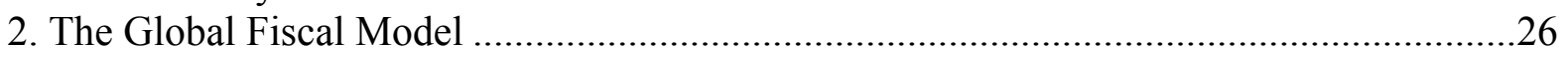

Appendix Tables

8. Stylized Example of How to Calculate the Primary Gaps ...............................................24

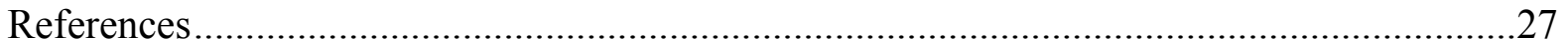




\section{INTRODUCTION}

In the coming decades, rising longevity, falling fertility rates, and the retirement of the baby boom generation will substantially raise age-related government spending in G-7 countries. By 2050, the populations in most G-7 countries are expected to be smaller and considerably older, with old-age dependency ratios projected to double. These trends will put national fiscal positions under substantial additional pressure. According to the projections submitted by national authorities, general government age-related spending in these countries is expected to rise by an average of 4 percentage points of GDP over the next 45 years with substantial cross-country variation.

This paper uses two standard indicators to assess the evolution of fiscal sustainability for each of the G-7 countries, and evaluate the contribution of policy initiatives. ${ }^{2}$ The first indicator, the debt target primary gap, measures the difference between the current primary fiscal balance (that is, revenue less non-interest expenditure) and the primary fiscal balance required to reach a target level of the gross public debt-to-GDP ratio in a certain year. The second indicator, the intertemporal primary gap, measures the change in the primary balance required to equate the present discounted value of future primary balances to the current level of debt. This measure thus indicates the adjustment required to stabilize debt at a level that is permanently sustainable (not just attained in a certain year, as is the case with first indicator).

In addition, the paper examines the macroeconomic consequences of adjusting fiscal policy to ensure long-run sustainability using the IMF's Global Fiscal Model (GFM). GFM is a general equilibrium overlapping-generations model developed at the IMF to examine macroeconomic and structural fiscal policy issues, including pension reform, in a multicountry setting. In particular, the analysis compares the projected effects on GDP of bring fiscal policy onto a sustainable trajectory within the next-five years, with a scenario in which adjustment is postponed for ten years.

The following three main findings emerge from the analysis. First, ensuring long-run fiscal sustainability requires a substantial fiscal adjustment in all G-7 countries, averaging 3-4 percentage points of GDP. Without any fiscal adjustment, the expected increases in age-related spending imply explosive debt dynamics in all seven countries. Second, while the overall adjustment required to achieve long-run fiscal sustainability in G-7 countries is large, there are significant growth benefits to putting public finances on a sustainable footing in the near term versus delayed adjustment. Third, obtaining a consistent set of cross-country estimates for future age-related spending pressures is an important priority for future research. Inconsistencies between the age-related expenditure projections published by international institutions limit their comparability, and prevent a fully consistent cross-country analysis.

\footnotetext{
${ }^{2}$ The two indicators belong to the family of primary gap indicators (as discussed in Chalk and Hemming, 2000) that are based on the European Commission's (2004) approach to assessing fiscal sustainability. A similar approach is used in HM Treasury (2006).
} 
The remainder of the paper is structured as follows. Section II discusses age-related expenditure pressures, which are at the root of fiscal sustainability concerns. Section III quantifies the evolution of fiscal sustainability over 2001-2005 and assesses the impact of policy reforms, based on two widely used indicators. Section IV compares the macroeconomic effects of earlier versus later adjustment using GFM, and Section V concludes.

\section{Evolution OF Age-Related EXPEnditures}

In the coming decades, rising longevity, lower fertility rates, and the retirement of the baby boom generation will substantially change the demographics of the G-7 countries. By 2050, it is expected that the populations in most G-7 countries will be smaller and considerably older. According to Eurostat projections, life-expectancy in the EU countries will increase by about six years over the next five decades (European Commission, 2006a). Given the age-structure of European populations, the old-age population dependency ratio is projected to double from about 25 percent to 50 percent, owing to a small decline in the working-age population and a sharp expansion in the elderly population. ${ }^{3}$ At the same time, United National projections show the old-age population increasing by 80 percent on average in G-7 countries (Figure 1).

Such developments imply a substantial increase in age-related government spending. According to the projections submitted by national authorities, general government agerelated spending in these countries is expected to rise by an average of 4 percentage points of GDP over the next 45 years with substantial cross-country variation (Figure 1). ${ }^{4}$ Estimates vary substantially across countries from Canada at the high end, where age-related spending is projected to rise by 9 percentage points by 2050, to Italy and Japan on the low end, where such spending is projected to rise by just 2 percentage points. The bulk of the spending increase is expected to come from additional health costs, with long-term care and pension spending accounting for the remainder.

Assessing the impact of these demographic changes on the sustainability of public finances is complicated by uncertainties about long-term technological, demographic, labor supply, and productivity growth projections. A key issue is the strength of the link between aging and the cost of health care. The more traditional "expansion of morbidity" hypothesis (aging implies longer periods of illness and thus higher costs) is often contrasted with the "compression of morbidity" hypothesis (aging delays, but does not extend, the periods of illness and the associated costs).

\footnotetext{
${ }^{3}$ The old-age dependency ratio is defined as the ratio of the population that is either older than 65 years to the labor force.

${ }^{4}$ See Economic Policy Committee of the European Union (2006) for France, Germany, Italy, and the United Kingdom; and OECD (2001) for Canada, Japan, and the United States. More recent long-run age-related spending projections for Canada, Japan, and the United States produced by national authorities are broadly consistent with the OECD (2001) projections.
} 
Figure 1. Projected Cumulative Growth in Old-Age Population and Increase in AgeRelated Spending Relative to 2005

- Age-related spending, in percent of GDP, left scale

- - Cumulative growth in old-age population, in percent, right scale
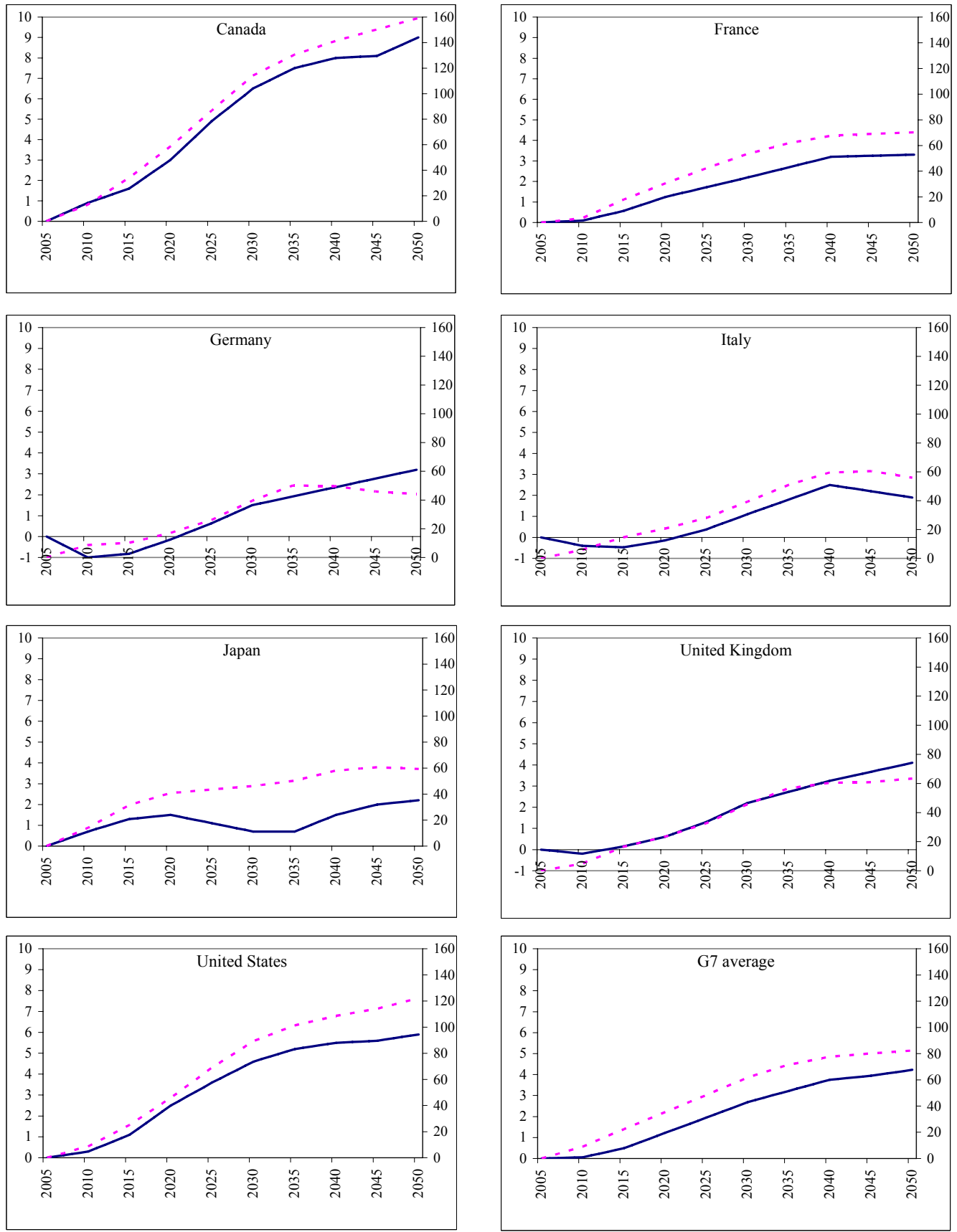

Sources: The old-age population projections are from United Nations (2005); the age-related spending projections for EU countries are from the Economic Policy Committee of the European Union (2006); and the age-related spending projections for the remaining countries are from the OECD (2001). 
A comparison of age-related spending pressures across countries is complicated further by differences in methodology across age-related spending projections. The absence of a fully standardized projection framework is rooted in the complexity of preparing population-cohort-based long-term projections for countries with different old-age and health insurance systems. Nonetheless, there is a fairly close relationship between the projected old-age population growth rates and projected age-related expenditure (Figure 1). Obtaining a more consistent set of cross-country estimates for future age-related spending pressures is therefore an important priority for future research.

Overall, the uncertainty surrounding long-term expenditure projections suggests that fiscal policy should not rely on baseline projections alone, but also recognize the upside risks to these projections. A "medium" scenario should not be the sole focus in the debates, and more attention should be paid to "worse case," although not necessarily "worst case," scenarios.

\section{Evaluating Changes in Fiscal Sustainability}

\section{A. Indicators for Assessing Fiscal Sustainability}

This paper uses two standard indicators to assess the evolution of fiscal sustainability for each of the G-7 countries, and evaluate the contribution of policy initiatives. ${ }^{5}$ The first indicator, the debt target primary gap, measures the difference between the current primary fiscal balance (that is, revenue less non-interest expenditure) and the primary fiscal balance required to reach a target level of the gross public debt-to-GDP ratio in a certain year. The second indicator, the intertemporal primary gap, measures the change in the primary balance required to equate the present discounted value of future primary balances to the current level of debt. This measure thus indicates the adjustment required to stabilize debt at a level that is permanently sustainable (not just attained in a certain year, as is the case with first indicator).

Both indicators consist of three components. The first component is the primary deficit component, i.e., the initial cyclically-adjusted general government primary deficit. A 1 percentage point of GDP increase in primary balance reduces both primary gap indicators by 1 percentage point. The second element is the debt component, i.e., the debt servicing costs of the initial debt stock (evaluated using either gross debt or net debt data). A 1 percentage point increase in the initial debt stock increase both primary gap indicators by a factor related to the growth-adjusted interest rate (nominal interest rates minus nominal growth). The third component is the aging component, i.e., the net present value of the projected increase in age-related expenditures times the growth-adjusted interest rate. For both indicators, the impact of the projected increase in age-related expenditures is non-linear and depends on the time profile of the expenditure increase and the assumed growth-adjusted interest rate.

\footnotetext{
${ }^{5}$ The two indicators belong to the family of primary gap indicators (as discussed in Chalk and Hemming, 2000) that are based on the European Commission's (2004) approach to assessing fiscal sustainability. A similar approach is used in HM Treasury (2006).
} 
Figure 2. Closing the Primary Gap: Gross Debt Dynamics, 2005-2080 (Percent of GDP)

- Closing the debt-target primary gap

- - - Closing the intertemporal primary gap
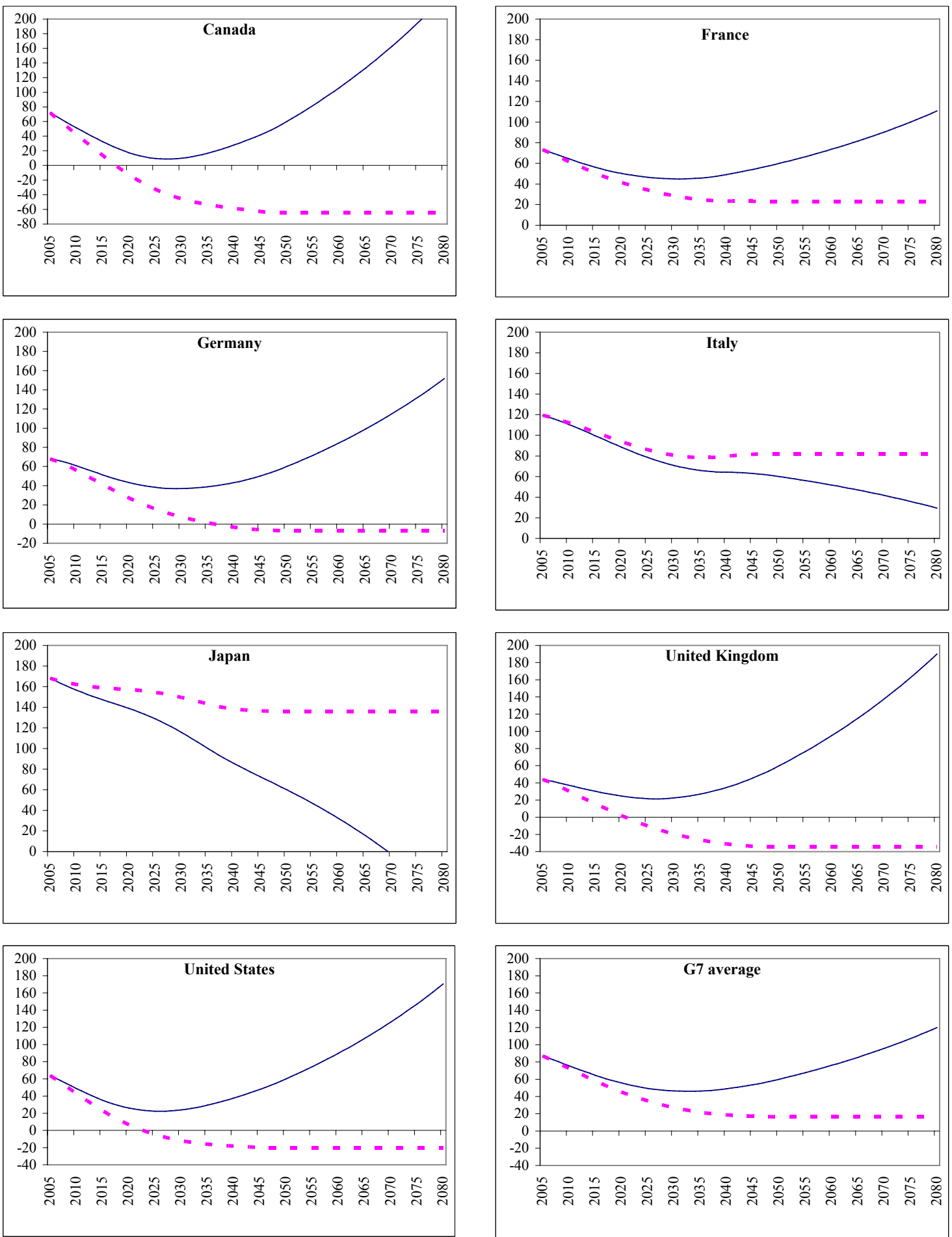
It is important to emphasize that closing the inter-temporal gap differs from the debttarget indicator in that it guarantees that the debt ratio stabilizes at a permanently sustainable level. For example, as Figure 2 illustrates, while closing the debt-target gap is sufficient for achieving the 60 percent-of-GDP target in 2050, debt dynamics are explosive thereafter. ${ }^{6}$ In contrast, closing the intertemporal primary gap stabilizes the debt-to-GDP ratio at a permanently sustainable level that reflects the interaction of the initial debt and the future age-related spending pressures.

\section{B. Data}

The age-related expenditure projections used to calculate the two primary gap indicators are those prepared by the national authorities for cross-country publications. In particular, for the G-7 countries that are EU members, the source is the most recent report by the Economic Policy Committee (2006). For the other three countries the source is OECD (2001), the most recent study by an international organization providing projections of total age-related expenditure (health, long-term care, and pensions) that are based on an at least partially standardized methodology. ${ }^{7}$ For each of these three countries, more recent projections by the authorities suggest even larger increases in age-related spending than those reported in OECD (2001). ${ }^{8}$ More recent projections for these three countries that were prepared according to an at least broadly comparable methodology are available from OECD (2006a), albeit only for health and long-term care; they are used in a sensitivity analysis.

In all cases, expenditures are interpolated linearly between the projection dates available in the respective sources. After 2050, age-related expenditures are assumed to stay constant. As is common in the literature, all other non-interest expenditures and revenues are assumed to remain constant for the whole projection period.

The calculation of the net present values of the expenditure paths in first instance assumes a growth-adjusted interest rate of 2 percent for all countries and years. While there are clearly arguments against using the same rate across countries and periods, this approach

\footnotetext{
${ }^{6}$ Note that, in Figure 2, the annual change in the debt-to-GDP ratio equals the primary balance plus the product of the growth-adjusted interest rate and the debt-to-GDP ratio in the previous period. With an adjustment in the primary balance based on the debt-target indicator, the yearly change of the debt-to-GDP ratio after 2050 can be ever increasing or ever decreasing depending on the size of the adjustment.

${ }^{7}$ Note that the OECD (2006b) study projects only health and long-term care expenditure.

${ }^{8}$ For example, the CBO (2005a) baseline projection for the increase in US federal spending on social security, Medicare, and Medicaid by 2050 is 10.6 percentage points of GDP, compared to only 6 percentage points reported by the OECD (2001). The Japanese Ministry of Health, Labor, and Welfare (2004) projects an increase in age-related government expenditure by 4 percentage points of national income, compared to only 1 percentage point of GDP in OECD (2001). The Canadian Department of Finance (2005) forecasts government health spending to rise by 6 percentage points of GDP, compared to 4 percentage points in OECD (2001). While these discrepancies may be explained to a considerable degree by differences in timing, methods, and assumptions, they highlight the large uncertainties surrounding age-related spending projections.
} 
ensures focus on the policy-driven aspects of sustainability. Nonetheless, as the robustness analysis reported below confirms, replacing the assumption of a 2 percent growth-adjusted interest rate with a 1 percent rate assumption does not substantially change the results.

The public debt and primary fiscal surplus data come from the OECD Economic Outlook database. Table 1 reports the data used for the analysis. In view of the analysis' long-term nature, this paper uses the cyclically adjusted fiscal balance prepared by the OECD. Both gross and net government debt data (net of financial assets) are used. The difference between the OECD gross and net debt measures is 33 percentage points of GDP on average in the G-7 countries. In Japan, the difference is particularly large at 87 percentage points of GDP. ${ }^{9}$

Table 1. Fiscal Positions as of 2005

\begin{tabular}{lcccc}
\hline & & & & $\begin{array}{c}\text { Projected Increase in } \\
\text { Age-Related Spending }\end{array}$ \\
& $\begin{array}{c}\text { Get Debt in } \\
\text { of GDP, end-2005 }\end{array}$ & $\begin{array}{c}\text { Sercent of GDP, } \\
\text { end-2005 }\end{array}$ & $\begin{array}{c}\text { Balance in Percent } \\
\text { of GDP, 2005 }\end{array}$ & $\begin{array}{c}\text { in Percentage Points } \\
\text { of GDP, 2005-50 }\end{array}$ \\
\hline Canada & 70.8 & 30.2 & 5.5 & 9.0 \\
France & 76.1 & 43.7 & -0.2 & 3.3 \\
Germany & 71.1 & 51.5 & 0.1 & 3.2 \\
Italy & 120.4 & 95.1 & 1.4 & 1.9 \\
Japan & 173.1 & 86.4 & -3.0 & 2.2 \\
United Kingdom & 46.7 & 40.0 & -1.5 & 4.1 \\
United States & 61.8 & 43.5 & -1.8 & 5.9 \\
\hline Average & 88.6 & 55.8 & 0.1 & 4.2 \\
\hline
\end{tabular}

Sources: OECD Economic Outlook database; EPC (2006); and OECD (2001).

Note: All data are for general government. Differences between OECD and IMF World Economic Outlook debt data may arise due to (i) different definitions of general government; (ii) alternative treatment of government assets and liabilities, notably pension liabilities; and (iii) alternative government account consolidating methods.

\footnotetext{
${ }^{9}$ The OECD Economic Outlook provides further information on the net financial assets used to construct the net debt data.
} 


\section{Estimation Results: Primary Gaps}

Under either measure, the estimated fiscal adjustment required to ensure long-run fiscal sustainability is substantial for all G-7 countries. In particular, as Table 2 reports, attaining a gross debt ratio of 60 percent of GDP by 2050 (debt-target indicator) would require an average improvement in the primary balance by 3.9 percentage points of GDP for the seven countries. ${ }^{10}$ Similarly, closing the intertemporal primary gap would require an average adjustment estimated at 3.9 to 4.5 percentage points of GDP (depending on whether net debt or gross debt is used to evaluate the indicator). ${ }^{11}$ Almost two-thirds of this adjustment reflects the expected increase in age-related spending (aging component), while the remaining one-third reflects the interest on public debt (debt component). The largest primary gaps are shown for Japan, reflecting the largest primary deficit and high debt level in 2005, and the United States, due to a combination of high primary deficits and high projected increases in age-related spending. The smallest primary gap is shown for Canada, where a primary surplus of 5.5 percent of GDP helps to offset the impact of the very large projected increase in age-related spending.

Table 2. Estimation Results: Primary Gaps in 2005

(Percent of GDP)

\begin{tabular}{|c|c|c|c|c|c|c|c|c|}
\hline & \multirow{2}{*}{$\begin{array}{c}\text { Debt Target } \\
\text { Primary Gap }\end{array}$} & \multicolumn{2}{|c|}{ Intertemporal Primary Gap $^{2}$} & \multicolumn{3}{|c|}{$\begin{array}{l}\text { Contributions to Intertemporal } \\
\text { Primary Gap (Gross Debt) from: }\end{array}$} & \multicolumn{2}{|c|}{ Intertemporal Primary Gap ${ }^{3}$} \\
\hline & & Net Debt & Gross Debt & $\begin{array}{c}\text { Primary } \\
\text { Balance4/ }\end{array}$ & $\begin{array}{c}\text { Debt } \\
\text { Service }\end{array}$ & $\begin{array}{l}\text { Aging } \\
\text { Costs }\end{array}$ & Net Debt & Gross Debt \\
\hline Canada & -0.5 & -1.4 & -2.2 & 5.5 & -1.4 & -6.3 & -2.3 & -2.7 \\
\hline France & -3.5 & -3.4 & -4.0 & -0.2 & -1.5 & -2.3 & -3.4 & -3.7 \\
\hline Germany & -2.1 & -2.7 & -3.0 & 0.1 & -1.4 & -1.7 & -2.8 & -3.0 \\
\hline Italy & -2.5 & -1.7 & -2.2 & 1.4 & -2.4 & -1.2 & -1.0 & -1.3 \\
\hline Japan & -9.0 & -6.2 & -7.9 & -3.0 & -3.4 & -1.6 & -5.6 & -6.5 \\
\hline United Kingdom & -3.6 & -4.8 & -4.9 & -1.5 & -0.9 & -2.5 & -5.1 & -5.1 \\
\hline United States & -6.1 & -6.9 & -7.3 & -1.8 & -1.3 & -4.2 & -7.2 & -7.4 \\
\hline Average & -3.9 & -3.9 & -4.5 & 0.1 & -1.8 & -2.8 & -3.9 & -4.2 \\
\hline
\end{tabular}

Sources: European Commission (2006a), OECD (2001), OECD Economic Outlook database, and IMF staff calculations.

${ }^{1}$ Target date: 2050

${ }^{2} 2$ percent growth-adjusted interest rate.

${ }^{3} 1$ percent growth-adjusted interest rate.

${ }^{4}$ The contributions are presented for calculations using the baseline 2 percent growth-adjusted interest rate.

\footnotetext{
${ }^{10}$ In addition to the Maastricht Treaty 60 percent-of-GDP public debt limit, and the 2050 target date used by the European Commission, alternative debt target values and years were considered by way of sensitivity analysis. Lowering the debt target from 60 to 50 percent of GDP implies the need for an additional adjustment averaging 0.14 percentage points of GDP. Shortening the target horizon from 2050 to 2015 implies the need for an additional adjustment averaging 0.4 percentage points of GDP.

${ }^{11}$ While using net debt to evaluate fiscal sustainability is preferable in principle, methodological inconsistencies, notably in the evaluation of pension system assets, imply that net debt figures cannot always be easily comparable across countries.
} 
In addition, rolling estimates of the intertemporal primary gaps indicate a deterioration in fiscal sustainability over 2001-2005. This deterioration averages 2.7 percentage points of GDP for the G-7 countries. Only in the case of Japan does the indicator improve over the five year period, although the end-2005 position for Japan is still estimated as unsustainable.

Figure 3 suggests that deteriorations in the primary fiscal balance contributed most to the deterioration in fiscal sustainability. The figure decomposes the intertemporal primary gap into three components, i.e. changes in the cyclically-adjusted primary fiscal balance; changes in the debt-to-GDP ratio; and a demographic component tied to changes in longterm age-related expenditure projections. The estimates do not take into account policy initiatives since end-2005. Estimates of the intertemporal primary gap indicator over 2001-05 are illustrated in Figure 3, where the G-7 average is found in the bottom right part of the figure.

The primary fiscal balance deteriorated by 2.8 percentage points of GDP during 2001-05. However, the average value of the primary fiscal balance component did improve during 2004-05 due to the reduction in the primary deficit in Japan. The deterioration in the component for the other countries reflects declining structural primary balances that have a one-to-one impact on the primary gap. The largest change occurred in the U.K. and the U.S., stemming from a deterioration in the primary balance by $5 \frac{1}{2}$ percentage points of GDP in both countries. Finally, the calculations suggest that, in 2001, the fiscal balance components for all countries except Japan were supportive of fiscal sustainability, and were providing additional fiscal space that could have been used to absorb future aging pressures.

The public debt component also contributed to widening the primary gaps over 2001-05 but by far less than the fiscal balance component. On average, the component deteriorated by 0.1 percentage points of GDP during 2001-05. While the value of the component deteriorated on average, it improved in Canada, the U.K. and Italy. In Japan, the increase in gross public debt over the past five years added 0.6 percentage points of GDP to the country's primary gap.

The demographic component improved by $1 / 4$ percentage points on average during 2001-05. The improvement reflects changes in age-related spending projections in Germany, France, and Italy, associated with the reforms described in Table 3. The greatest improvement is estimated for France, where the 2003 reforms reduced the primary gap by 0.9 percentage points. In Germany and Italy, the recent pension reforms reduced the primary gap by 0.4 percentage points of GDP.

Most G-7 countries recently have undertaken substantial reforms to contain the growth of age-related spending. A summary of many of these reforms and their estimated future fiscal savings is provided in Table 3. Over the past five years, more progress has been seen in the area of pensions than in health care - with France, Germany, Italy and Japan having passed pension reforms that should bring sizeable expenditure savings. Nevertheless, it is generally agreed - and confirmed by the analysis here - that additional structural reforms 
Figure 3. Rolling Estimates of the Intertemporal Primary Gap, 2001-05

\section{(In percent of GDP)}

$\square$ fiscal deficit
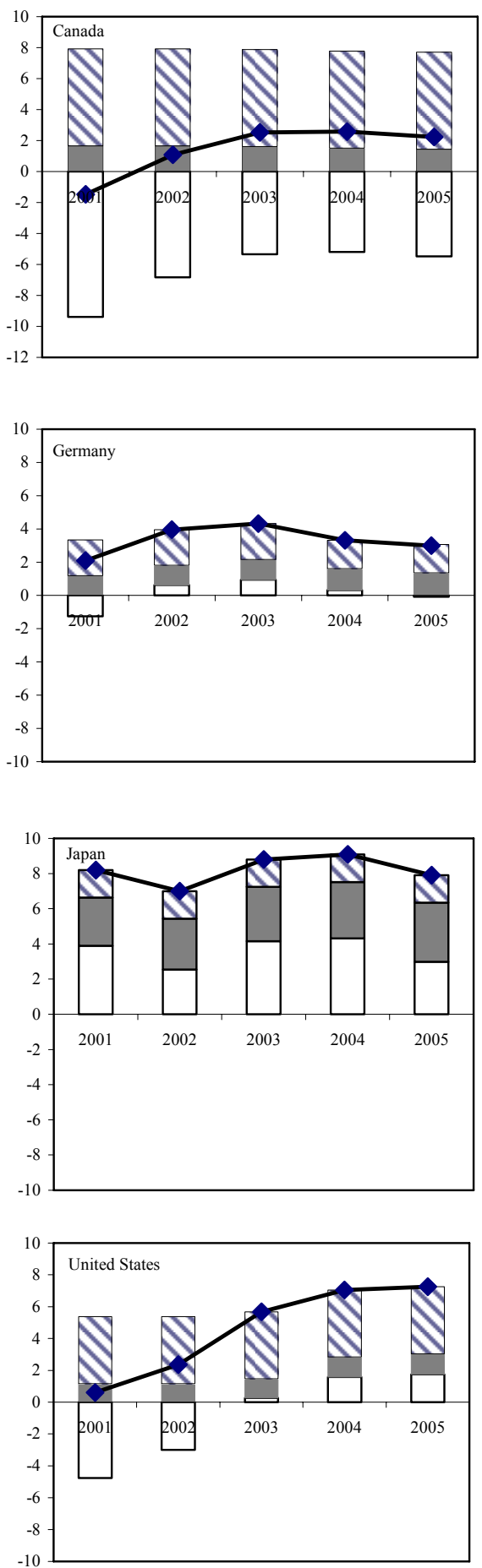

N aging
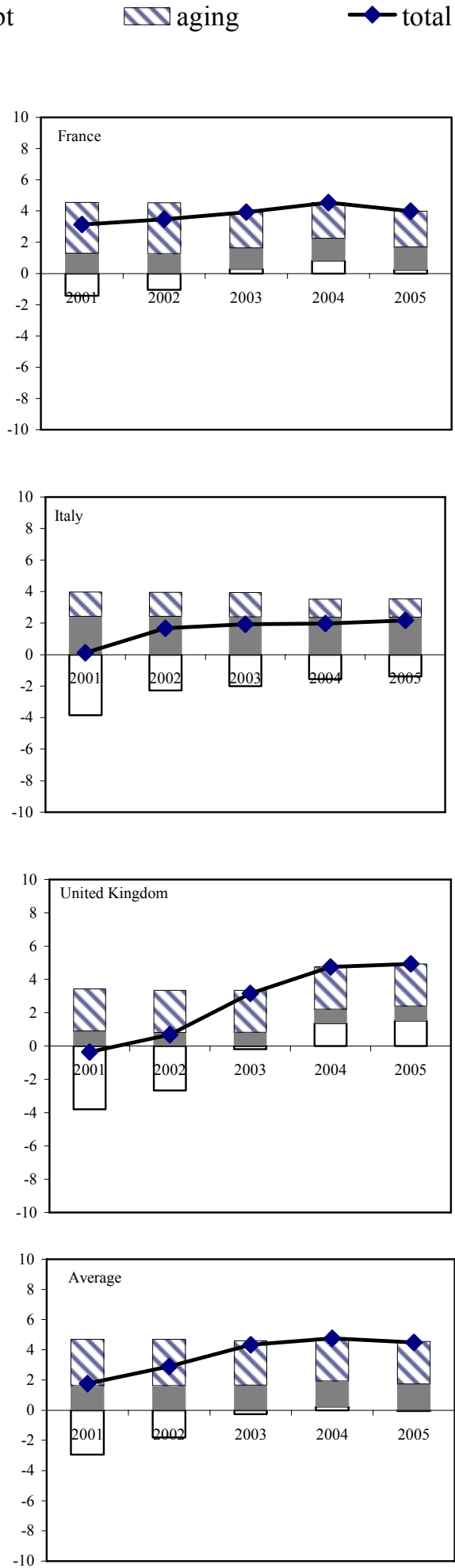

Source: OECD (2001) and EC (2006) age-related spending projections, OECD (2006) public debt, cyclically adjusted primary deficit, and GDP data, and authors' calculations.

Note: chart shows total intertemporal primary gap, and the relative contributions of the primary fiscal deficit (a negative contribution implies a primary fiscal surplus), public debt stock, and expected age-related spending. 


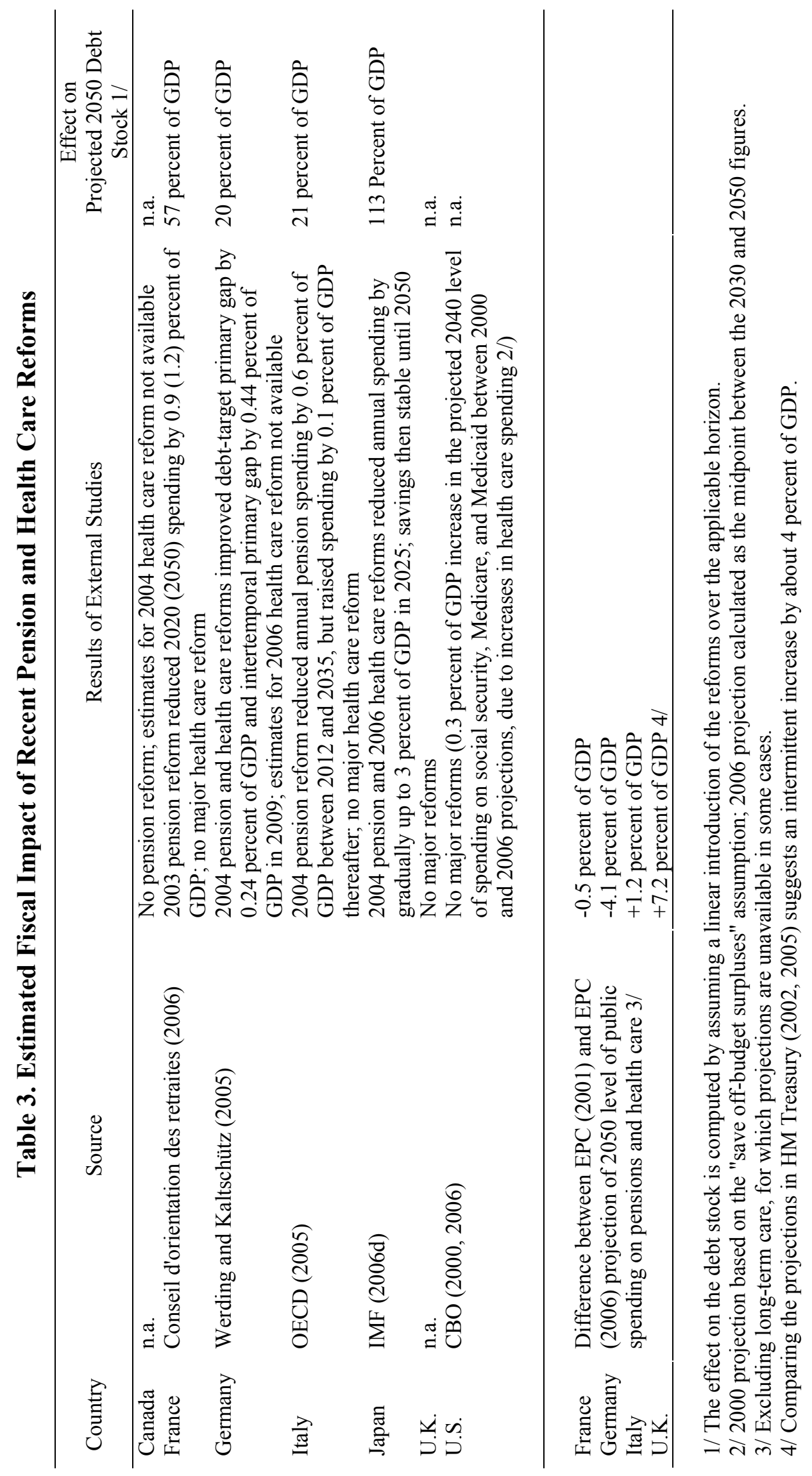


or fiscal consolidation in other areas will be required. At present, new reforms are in the offing, notably health care reforms in Germany and Japan.

For the EU countries, a comparison of the results of two rounds of projections by the European Commission in part corroborates this paper's findings on the aging component. As shown in the lower part of Table 3, the projected 2050 level of public spending on pensions and health care has changed substantially between the 2001 and 2006 rounds. It has fallen for France and Germany, but increased for Italy and the U.K.. Thus, the direction of the change in the aging component of fiscal sustainability is consistent between the calculations above and those from the European Commission in the cases of France, Germany, and the U.K.; however, for Italy the results in this paper suggest an improvement, while the European Commission's findings indicate a deterioration. This difference is likely due to changes in the methodology between the two rounds of European Commission projections that are unrelated to reforms.

\section{Robustness}

This section discusses the robustness of the primary gap indicators to alternative underlying assumptions. In particular, the analysis re-evaluates the sustainability indicators based on alternative future age-related spending paths, alternative growth-adjusted interest rates, and, for the debt-target indicator, alternative target years and debt targets.

\section{Alternative Target Years for the Debt-Target Indicator}

In principle, shortening the targeting horizon can have ambiguous effects on the estimated debt-target primary gap. Reducing the target year can raise or lower the primary gap depending on the initial debt stock and the severity and time profile of the age-related expenditure pressures. Shortening the horizon places a greater weight on the initial debt stock and the debt target, and less weight on the aging costs. When the initial debt stock is lower than the target and the age-related spending increase occurs with a delay, the required fiscal adjustment is smaller for a shorter horizon than for a longer time horizon. The primary gap could even change sign if the time horizon is sufficiently short and the debt target sufficiently high. However, in this case, the results are no longer informative regarding the implications of population aging, which is pronounced only from 2015 onwards.

The analysis indicates that, for the average G-7 country, the required fiscal adjustment is on average about $1 / 2$ percentage points of GDP higher if the target date is changed from 2050 to 2015. The larger adjustment need with a shorter time horizon reflects the relatively high debt ratios - especially in Italy and Japan - in the G-7 countries. The required adjustment is smaller if the target year is 2030 (instead of 2050), in part reflecting the fact that countries then have more time to reduce debt while aging costs increases have not yet fully materialized. When 2015 is used as the target year, the needed fiscal adjustment is rises to 4.3 percentage points of GDP from 3.9 percentage points of GDP when 2030 is used as the target year. However, there is substantial cross-country regarding the impact of changing the debt-target horizon on the debt-target primary gap. When the target year changes from 2050 to 2015, the primary gap doubles from 9 percent to 17 percent of GDP for Japan, whereas, for other countries, with the exception of Italy, it declines (Table 4). 
Table 4. Debt-Target Primary Gap for Alternative Target Years: 60 Percent Debt-to-GDP Ratio Target

(Percent of GDP)

\begin{tabular}{lrrr}
\hline & 2015 & 2030 & 2050 \\
\hline Canada & 2.0 & 0.0 & -0.5 \\
France & -3.1 & -3.4 & -3.5 \\
Germany & -1.3 & -1.6 & -2.1 \\
Italy & -6.1 & -3.0 & -2.5 \\
Japan & -16.9 & -10.8 & -9.0 \\
United Kingdom & -0.9 & -2.8 & -3.6 \\
United States & -3.9 & -5.7 & -6.1 \\
\hline G7 average & -4.3 & -3.9 & -3.9 \\
\hline
\end{tabular}

\section{Alternative Debt Targets for the Debt-Target Primary Gap}

To assess the impact of changing the debt target, the debt-target indicator is recomputed for debt targets 10 and 20 percentage points of GDP lower than in the baseline target of 60 percent of GDP. The results indicate that the primary gap is a linear function of the chosen debt target for a given growth-adjusted interest rate. The impact of reducing the debt target by 10 percentage points of GDP is estimated at 0.14 percentage point of GDP (Table 5) for each G-7 country.

Table 5. Impact of Changing the Debt Target on Debt-Target Primary Gap (Percent of GDP)

\begin{tabular}{lc}
\hline & Impact to debt target primary gap compared to baseline \\
\hline Lowering debt target by 10 percent of GDP & -0.14 \\
Lowering debt target by 20 percent of GDP & -0.28 \\
\hline
\end{tabular}

\section{Alternative Scenarios for the Increase in Age-related Expenditures}

To assess the sensitivity of the results to alternative age-related expenditure projections, the intertemporal primary gap indicator is re-computed under an alternative scenario in which projected aging cost are 1 percentage point of GDP higher than in the baseline. This additional increase in age-related expenditures is assumed to occur gradually over the period to 2050 in a way that is similar to the country-specific profile for aging costs in the baseline projection.

An upward revision in aging costs of 1 percentage point of GDP on average raises the estimated need for fiscal adjustment by 0.7 percentage point of GDP. This result is relatively stable across the G-7 countries (Table 6). This finding underscores the implications of the uncertainties surrounding the calculation of the sustainability indicators as the results prove to be rather sensitive to changes in long-term projections of age-related expenditures. Given that for some of the countries the aging projections differed by more than $2 \frac{1}{2}$ percentage 
points of GDP, the impact on the required fiscal adjustment to restore sustainability is material.

An additional sensitivity test for those countries for which the source of the baseline projections is the OECD (2001) study involves updating the health and long-term care components based on the more recent OECD (2006) publication. Because the OECD (2006) study does not provide updated projections for pensions, the pension-related expenditure forecasts remain as in the OECD (2001) study. The OECD (2006) study provides three projection scenarios, namely, "demographic," "cost containment," and "cost pressure," with the latter involving the largest spending increase. For the purposes of this paper, the analysis uses the average of the "cost containment," and "cost pressure" scenarios. Accordingly, spending in Canada and Japan is projected to increase more than the OECD (2001) study, while it is projected to increase less for the United States. As Table 6 reports, using these updated projections results in a change of less than 0.5 percent of GDP in the estimated primary gap indicators for Canada and the United States, but an increase in the primary gap for Japan by 2.1 percent of GDP (Table 6). The result for Japan is due to the increase in projected health and long-term care spending in the updated OECD (2006) study to 5.5 percent of GDP from 2.2 percent of GDP in the original study.

Table 6. Impact of Higher Aging Costs on Intertemporal Primary Gap (Percent of GDP)

\begin{tabular}{lcc}
\hline & Baseline +1 percent of GDP & $\begin{array}{c}\text { Average of OECD (2006) "cost containment" and "cost } \\
\text { pressure" scenarios for health expenditures }\end{array}$ \\
\hline Canada & -0.7 & -0.3 \\
France & -0.7 & \\
Germany & -0.5 & -2.1 \\
Italy & -0.6 & \\
Japan & -0.7 & +0.4 \\
United Kingdom & -0.6 & \\
United States & -0.7 & \\
G-7 Average & -0.7 & \\
\hline
\end{tabular}

\section{Alternative Growth-adjusted Interest Rate Assumptions}

Changing the growth-adjusted interest rate assumption affect the estimated primary gaps through two channels with opposite effects. On the one hand, for any given stock of net public debt, a higher interest rate increases the interest cost component of the primary gap. On the other hand, when the interest rate increases, future age-related expenditures are discounted using a higher interest rate, and this reduces the aging component of the intertemporal primary gap. Thus, while a lower interest rate improves the debt component of the intertemporal gap, it worsens the aging component as more weight is attached to future expenditures increases. 
Overall, reducing the growth-adjusted interest rate from 2 to 1 percent is found to reduce the intertemporal primary gap by 0.3 percentage point of GDP. ${ }^{12}$ This result stems from a reduction in the estimated interest payments on current debt by 0.9 percentage points of GDP and an offsetting increase in the net present value of aging costs by 0.6 percentage points of GDP. Thus, for the average G-7 country, a change in the growth-adjusted interest rate has a larger effect on the sustainability indicator through the current debt stock than through the projected increase in age-related expenditures.

However, the interest rate sensitivity of the results varies considerably across countries, reflecting different debt stocks and aging costs (Table 7). For example, when the growth adjusted interest rate is 1 percentage point lower, the estimated primary gap declines by 1.4 percentage points of GDP for Japan, by the decline is only 0.9 percentage points for Italy. In contrast, for Canada, the United Kingdom, and the United States, the estimated adjustment need widens slightly.

Table 7. Effect on Intertemporal Primary Gap of Reducing the Growth-Adjusted Interest Rate by 1 Percentage Point

(Percent of GDP)

\begin{tabular}{lccc}
\hline & Total effect & Interest service on debt & NPV of aging costs \\
\hline Canada & -0.5 & 0.7 & -1.2 \\
France & 0.3 & 0.7 & -0.4 \\
Germany & 0.0 & 0.7 & -0.6 \\
Italy & 0.9 & 1.2 & -0.3 \\
Japan & 1.4 & 1.7 & -0.3 \\
United Kingdom & -0.2 & 0.4 & -0.7 \\
United States & -0.1 & 0.6 & -0.7 \\
\hline G-7 Average & 0.3 & 0.9 & -0.6 \\
\hline
\end{tabular}

\section{Delayed Versus Immediate Fiscal AdJustment: Macroeconomic EfFects}

This section compares the macroeconomic consequences of restoring fiscal sustainability in the near-term with delaying the adjustment by ten years. The discussion focuses on measures designed to restore fiscal sustainability on a permanent basis by closing the intertermporal primary gap. In particular, the two scenarios considered are as follows. The first scenario, the near-term adjustment scenario, involves closing the intertermporal primary gap over a period of five years. The adjustment is spread over five years as a more abrupt, one-time adjustment would often not be feasible for political-economy reasons. The second scenario, the delayed adjustment scenario, involves no changes in fiscal policy for ten years, during which age-related spending pressures are allowed to build up, and to affect the evolution of public debt and the primary balance. After 10 years, the scenario involves

\footnotetext{
${ }^{12}$ The effects of an increase in the growth-adjusted interest rate from 2 percent to 3 percent have the same magnitude, but the opposite sign.
} 
reassessing the intertemporal primary gap based on the as-of-then public debt and primary balance levels, and closing the primary gap over the following five years.

The effects of these two policy scenarios on economic activity - both in the short term, and in the medium to long term - are assessed using the IMF's Global Fiscal Model (GFM). GFM has been developed at the Fund to examine a number of fiscal policy issues including pension reform (see Appendix 2 for details). Regarding the calibration of the agerelated spending pressures, this section relies on the baseline projections discussed in Section II. While a wide variety of fiscal instruments can be explored using GFM, the analysis focuses on consolidations that rely on increases in payroll taxes.

Three main conclusions emerge from the analysis. First, delaying fiscal consolidation generally results in a substantial increase in public debt (Figure 4 reports results for all G-7 countries, as well as the average result). The exception to this finding is Canada, where the large initial primary surplus permits a steady reduction in debt even when fiscal consolidation is delayed. The largest increase in debt occurs in Japan, and is explained by the relatively high initial debt and fiscal deficit levels.

Second, delaying adjustment and allowing debt to increase also implies the need to run permanently higher primary surpluses to service the higher interest costs (Figure 5). On average, the primary balance required to stabilize debt on a sustainable basis is 1.1 percentage points of GDP higher in the long run than in the immediate adjustment scenario. The required additional long-run increase in the primary balance is most striking in the case of Japan, where it is estimated at $2 \frac{1}{2}$ percentage points of GDP. Note that this simulation does not take into account the Japanese authorities' plans to achieve primary balance (excluding social security) by 2011, which would result in a lower debt profile.

Third, in terms of the effects on economic activity, implementing the adjustment over the next five years is substantially less costly than postponing consolidation, and is associated with long-run output gains. This result is illustrated in Figure 6 and can be decomposed into the near term, the medium term, and long run. During the first five years, early adjustment results in lower growth by an average of 0.4 percentage points per year compared with the no-adjustment scenario. This initial contraction primarily reflects lower household consumption in response to the higher payroll taxes, and a decline in labor supply. The cumulative undiscounted output cost over the first five years of the early adjustment scenario averages 1.8 percentage points of GDP relative to the no-adjustment scenario. After completing the adjustment in five years, the economy grows faster by an average of 0.3 percentage points per year over the next 10 years compared with the delayed adjustment scenario. Over the same period, the delayed adjustment scenario involves lower growth on account of increasing crowding out effects, and a substantial increase in payroll taxes starting in the sixth year. After 15 years, growth in the two scenarios converges the same value. In the long-run, the faster growth in the early adjustment scenario implies a GDP level about 1.9 percent higher than in the delayed adjustment scenario. The long-run output gain accrues due to higher labor supply on account of the lower payroll taxes, and to higher investment 
Figure 4. Public Debt: Restoring Sustainability Immediately and with a Delay (In percent of GDP)
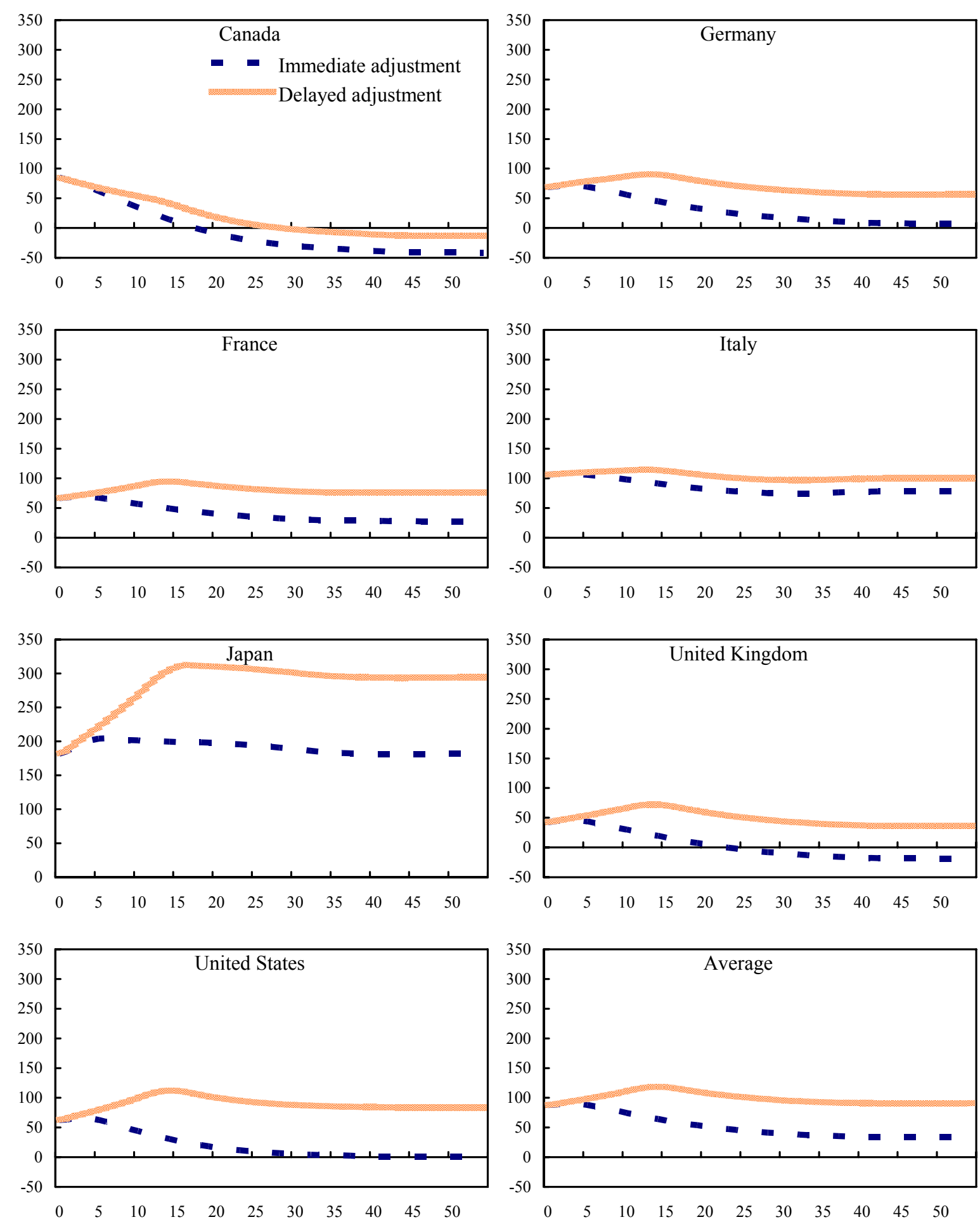

Source: GFM simulations.

Note: horizontal axis denotes vears. 
Figure 5. Primary Fiscal Balance: Restoring Sustainability Immediately and with a Delay (In percent of GDP)
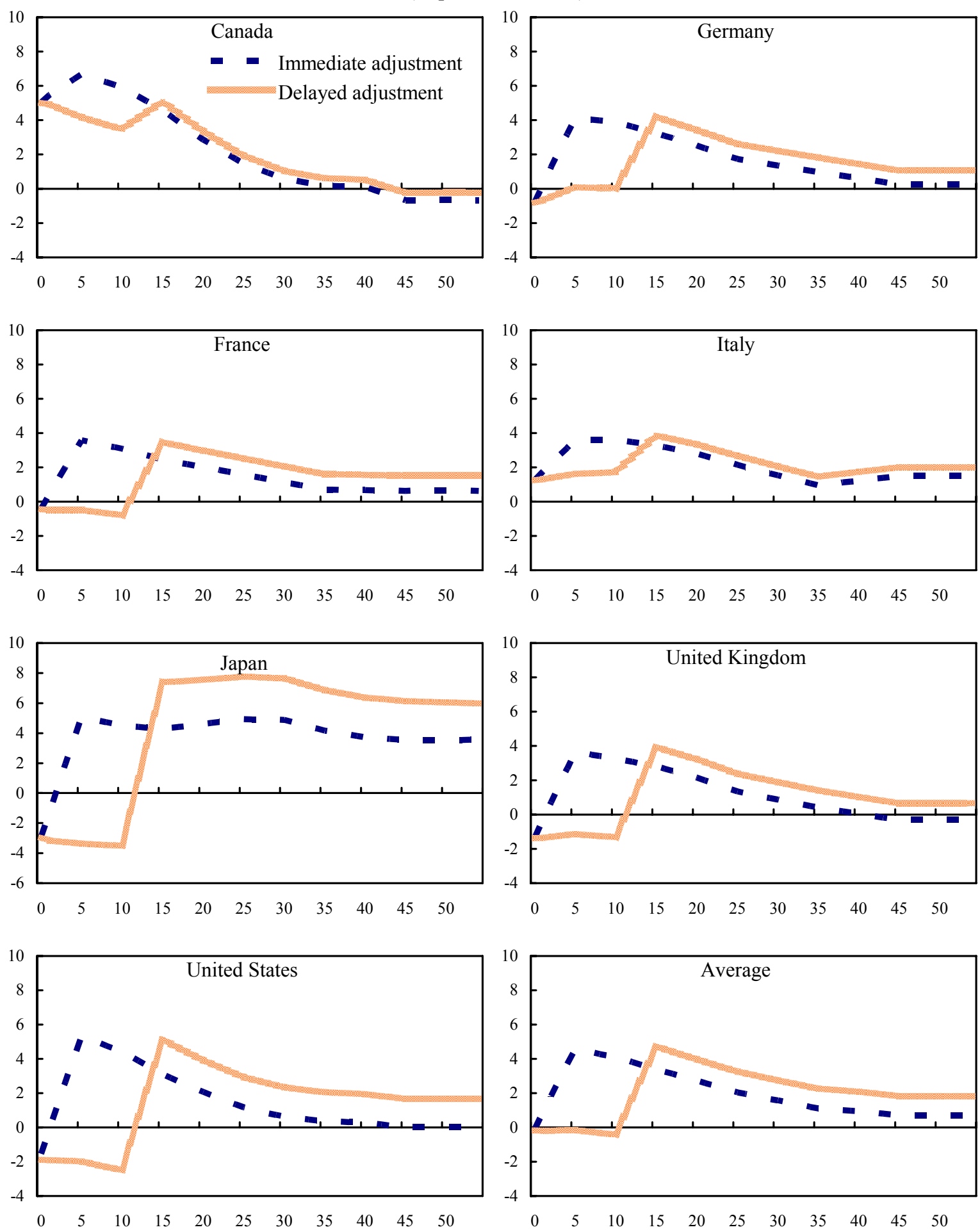

Source: GFM simulations.

Note: horizontal axis denotes years. 
Figure 6. Real GDP: Restoring Sustainability Immediately and with a Delay (In percent deviation from delay scenario)
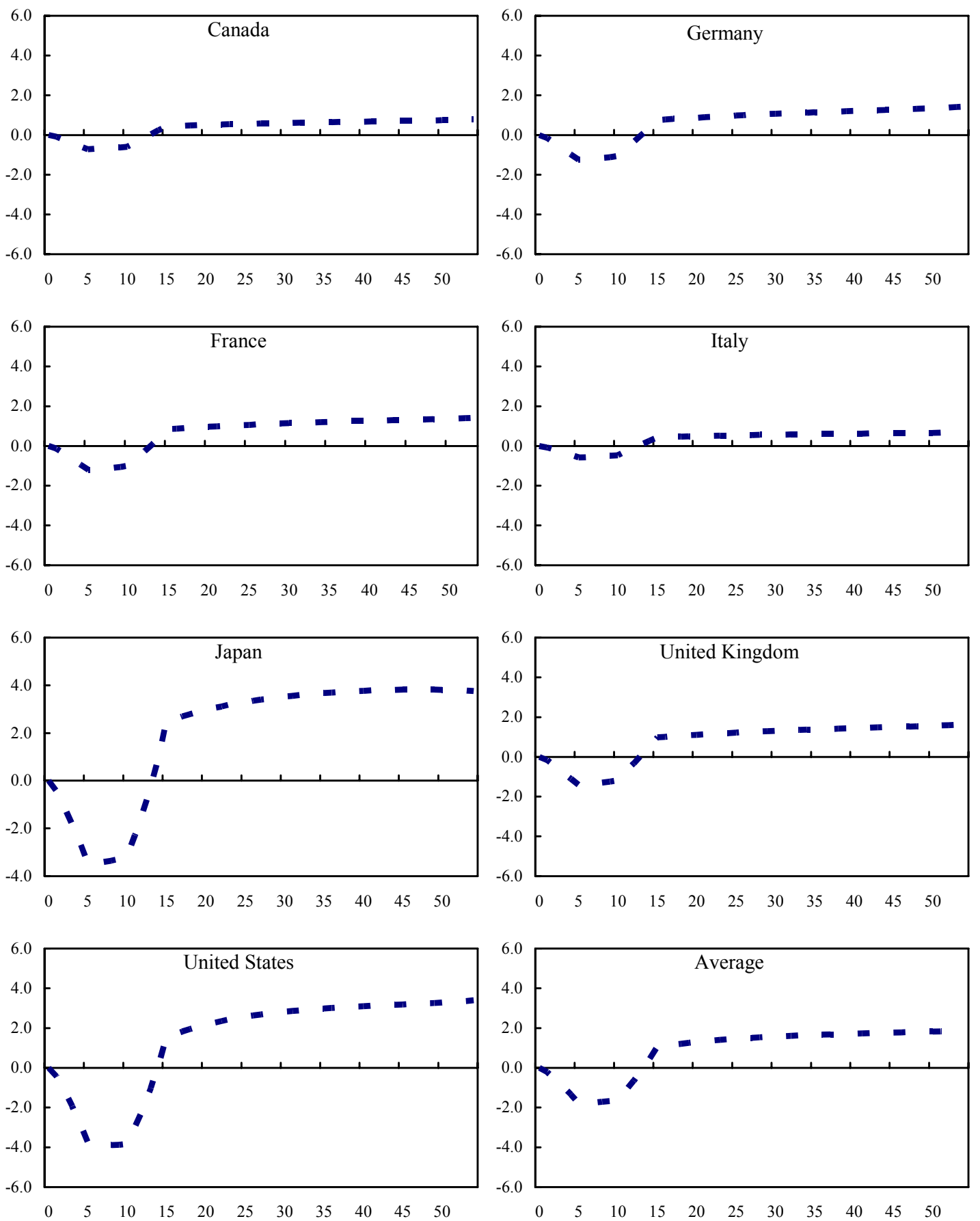

Source: GFM simulations.

${ }^{1 /}$ Figure reports the percentage point difference between level of real GDP in the immediate adjustment scenario and level of real GDP in the delayed adjustment scenario. 
reflecting lower debt and smaller crowding out effects. ${ }^{13}$ The long-run estimated benefit of early adjustment is largest for Japan where early adjustment prevents a substantial increase in debt and yields an estimated output gain of 3.8 percentage points of GDP.

\section{Conclusion}

Rising longevity, falling fertility rates, and the retirement of the baby boom generation will substantially raise age-related government spending in most advanced and many emerging market countries. This paper assesses the implications of these age-related spending pressures for fiscal sustainability in each of the G-7 countries using two standard primary gap indicators.

The analysis indicates that, while pension and health care reforms undertaken in G-7 countries in recent years have generated substantial savings, fiscal sustainability overall deteriorated in most G-7 countries during 2001-2005. This deterioration mainly reflects deteriorating primary fiscal balances. As of 2005, the estimated fiscal adjustment required to ensure long-run fiscal sustainability is substantial for all G-7 countries. In particular, ensuring fiscal sustainability would require an average improvement in the primary balance of about 4 percentage points of GDP.

In addition, the large adjustments required in the baseline scenario are subject to significant upside risks. For example, long-term age-related expenditure projections are surrounded by numerous uncertainties. Obtaining a consistent set of cross-country estimates for age-related spending pressures is an important priority for future research.

Finally, while the overall adjustment required to achieve long-run fiscal sustainability in G-7 countries is large, analysis using the Global Fiscal Model suggests that there are significant growth benefits to putting public finances on a sustainable footing in the near term versus delayed adjustment. Early adjustment is estimated to deliver a permanent output gain of about 2 percent of GDP on average. Postponing adjustment increases the size of the fiscal adjustment required to restore sustainability. Given the upside risks to spending pressures, early fiscal adjustment would also allow greater fiscal space to absorb any higher-thanexpected age-related expenditure needs.

\footnotetext{
${ }^{13}$ In addition, early adjustment would address inter-generational equity considerations by ensuring that the "baby boomer" generation bears some of the adjustment burden. However, intergenerational equity considerations are not explicitly evaluated using a welfare criterion in this paper.
} 


\section{Appendix I. Sustainability Indicators}

This appendix explains how the primary gap indicators are constructed. As indicated in the main text two indicators to assess the evolution of fiscal sustainability for each of the G-7 countries, and evaluate the contribution of policy initiatives. The first indicator, the debt target primary gap, measures the difference between the current primary fiscal balance (that is, revenue less non-interest expenditure) and the primary fiscal balance required to reach a target level of the gross public debt-to-GDP ratio in a certain year. The second indicator, the intertemporal primary gap, measures the change in the primary balance required to equate the present discounted value of future primary balances to the current level of debt. This measure thus indicates the adjustment required to stabilize debt at a level that is permanently sustainable (not just attained in a certain year, as is the case with first indicator).

The two primary gaps are derived from the government's overall budget constraint and can in technical terms be expressed the following way (European Commission, 2006b):

$$
\begin{gathered}
\text { PRIMARYGAP DEBTTARGET }=p d_{0}+\bar{r} \cdot\left(d_{-1}-\alpha \cdot d_{T}\right)-\bar{r} \cdot \overline{N P V} \\
\text { PRIMARYGAP INTERTEMPORAL }=p d_{0}+r \cdot d_{-1}-r \cdot N P V
\end{gathered}
$$

where $p d_{0}$ is the initial primary deficit, $d_{-1}$ is the initial debt stock, $d_{\mathrm{T}}$ is the debt target at target period $\mathrm{T}$ and $r$ is the growth adjusted interest rate assumed to be constant for all periods. The primary balance and debt stock are measured as a share of GDP. The net present value term NPV used for the intertemporal primary gap is the discounted value of the projected future change in the primary balance for all periods, whereas $\overline{N P V}$ used for the debt-target gap is the discounted value of the projected change in the primary balance until the target period T. The discount factor $\alpha, \mathbf{0} \leq \alpha \leq \mathbf{1}$ depends on the growth adjusted interest rate and the target year and indicates how much weight is attached to aging developments after time T. Finally, $\bar{r}$ is the adjusted growth adjusted interest rate which takes into account the non-indefinite time horizon when applying the debt-target indicator.

A change in the primary balance has a one-to-one effect on both sustainability indicators, whereas a 1 percentage point increase in the initial debt stock will reduce the indicators by $r$ percentage points of GDP and $\bar{r}$ percentage points of GDP, respectively. An increase in the debt target will raise the debt target indicator $\alpha \cdot \bar{r}$ percentage points of GDP, but will leave the intertemporal indicator unchanged.

A simple stylized example shows how the two indicators quantitatively can produce similar results. However, the contributions from the individual components and the implied debt dynamics differ. Consider a stylized economy with an initial primary deficit of 1 percent of GDP, an initial debt stock of 90 percent of GDP, a debt target of 60 percent of GDP, a growth adjusted interest rate of 2 percent, and aging costs increasing linearly by 5 percent of GDP during 2005-50 and stay constant as a share of GDP beyond 2050. If the target year for the debt-target indicator is assumed to be 2050 the $\alpha$ parameter equals 0.41 implying that 41 percent of the age-related expenditure dynamics entering the net present value calculation 
using the intertemporal indicator is not taken into account when the net present value of agerelated expenditures is calculated according to the debt-target indicator (i.e., the expenditure evolution happening after 2050). With the assumed parameters and time horizon an increase in the initial debt stock by 1 percentage point of GDP will reduce the intertemporal indicator by 0.020 percentage point of GDP and the debt-target indicator by 0.035 percentage points of GDP, whereas a similar increase in the debt target will raise the debt-target indicator by 0.014 percentage points of GDP.

With the chosen parameters in the stylized example, the debt-target indicator requires a fiscal adjustment of about $5 \frac{1}{2}$ percentage points of GDP, while the intertemporal indicator produces a needed adjustment of 6 percentage points of GDP to restore sustainability. For both indicators the deficit component contributes with 1 percentage point of GDP (Table 8). Even though the debt target is subtracted from the initial debt stock when computing the debt-target indicator the contribution from the debt component to the indicators is larger because the elasticity (the adjusted growth adjusted interest rate) is sufficiently higher than under the intertemporal indicator. However, the aging component is more than 1 percentage point of GDP higher when using the intertemporal indicator as the debt-target indicator does not take into account the higher level of expenditures after 2050.

Table 8. Stylized Example of How to Calculate the Primary Gaps (Percent of GDP)

\begin{tabular}{|c|c|c|}
\hline & Intertemporal Primary Gap & Debt-target Primary Gap \\
\hline \multicolumn{3}{|c|}{ Technical terms: } \\
\hline Deficit $1 /$ & $p d_{0}$ & $p d_{0}$ \\
\hline Debt & $-r \cdot d_{-1}$ & $-\bar{r} \cdot\left(d_{-1}-\alpha \cdot d_{T}\right)$ \\
\hline Aging & $r \cdot N P V$ & $\bar{r} \cdot \overline{N P V}$ \\
\hline \multicolumn{3}{|c|}{ Stylized example: } \\
\hline Deficit & -1.0 & -1.0 \\
\hline Debt & -1.8 & -2.2 \\
\hline Aging & -3.3 & -2.2 \\
\hline Primary gap & -6.1 & -5.4 \\
\hline \multicolumn{3}{|c|}{$\begin{array}{l}\text { 1/ The deficit component is shown with a negative sign as the primary balance and not the primary deficit enters } \\
\text { the indicator equations. }\end{array}$} \\
\hline $\begin{array}{l}\text { While con } \\
\text { ratio, closing } \\
\text { permanently } \\
\text { terms of the } \\
\text { run debt dyn } \\
\text { an increasing } \\
\text { stabilizes jus } \\
\text { using the int } \\
\text { substantially }\end{array}$ & $\begin{array}{l}\text { target indicator does not } \\
\text { nary gap indicator alway } \\
n \text { when the two indicator } \\
\text { ent-as in the stylized e } \\
\text { ifferent (Figure 7). For e } \\
\text { the debt-target indicator } \\
\text { GDP under the intertemp } \\
\text { so demonstrates that the } \\
\text { pproach and will in some }\end{array}$ & $\begin{array}{l}\text { tee a stable long-term debt } \\
\text { zes the debt ratio at a } \\
\text { ce a similar results in } \\
\text { above, the implied long- } \\
\text { the debt ratio ends up on } \\
\text { ied, while the debt ratio } \\
\text { licator. The debt dynamics } \\
\text { abilizing level differs } \\
\text { ces even be negative, }\end{array}$ \\
\hline
\end{tabular}


depending on the initial debt stock and primary balance as well as the profile of age-related expenditure increases.

Figure 7. Debt Dynamics and Aging Costs in the Stylized Example (Percent of GDP)
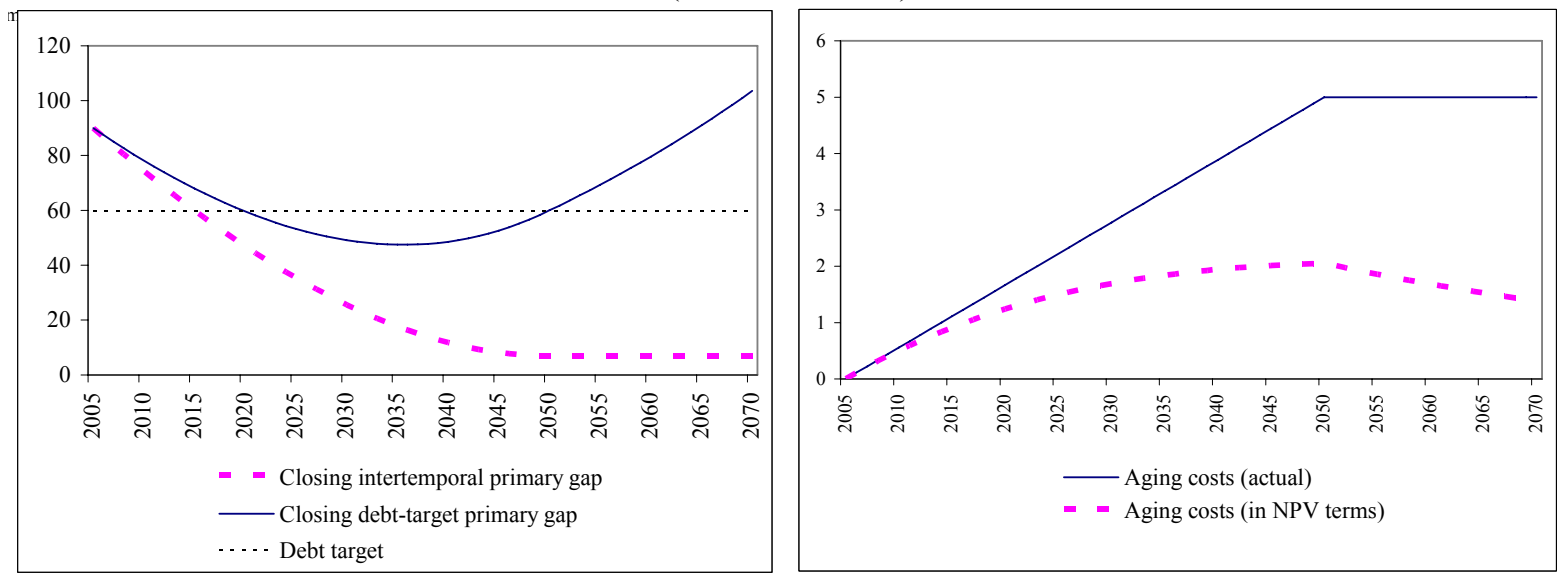


\section{Appendix II: The Global Fiscal Model}

The Global Fiscal Model (GFM) is a multicountry dynamic general equilibrium model based on the New Open Economy Macroeconomics (NOEM) tradition, but designed to examine fiscal policy issues. ${ }^{14}$ It is particularly suitable for studying temporary or permanent changes in taxes or expenditures, whether occurring rapidly or gradually (as is the case of age-related expenditure pressures). The GFM extends the NOEM framework by introducing non-Ricardian features via three distinct channels to allow for thorough fiscal policy analysis:

- $\quad$ Finitely-lived overlapping generations that imply that fiscal policy changes affect the households' incentives to consume and work as they discount future fiscal policy.

- $\quad$ Liquidity-constrained households that consume all their disposable income every period and thereby immediately respond to fiscal policy effects on disposable income.

- Distortionary labor and income taxes that effect incentives to consume and to invest.

Moreover, by incorporating monopolistic competition, short-term output in the model is partly demand-driven, and fiscal policy can have short-term effects on production. The multicountry feature of the GFM allows the analysis of international spillover effects as changes in government debt influence world interest rates. The GFM also features a rich menu of taxes that permits the analysis of the macroeconomic effects of a number of alternative fiscal-consolidation strategies. To ensure comparability of modeling results across different countries, underlying model parameters that are not expected to be affected by fiscal sustainability considerations are kept constant across countries.

\footnotetext{
${ }^{14}$ See Botman, Laxton, Muir, and Romanov (2006) for a detailed description of the GFM.
} 


\section{References}

Botman, Dennis, Dirk Muir, Andrei Romanov, and Douglas Laxton, 2006, "A New-OpenEconomy Macro Model for Fiscal Policy Evaluation,” IMF Working Paper 06/45 (Washington: International Monetary Fund).

Broda, Christian, and David E. Weinstein, 2004, "Happy News from the Dismal Science: Reassessing Japanese Fiscal Policy and Sustainability," NBER Working Paper No. 10988 (Cambridge: National Bureau of Economic Research).

Canadian Department of Finance, 2005, Budget 2005, Annex 3: Canada's Demographic Challenge (Ottawa).

Chalk Nigel, and Richard Hemming (2000), "Assessing Fiscal Sustainability in Theory and Practice, " IMF Working Paper 00/81 (Washington DC: International Monetary Fund).

Chand, Sheetal K., Albert Jaeger, and a Staff Team from the Fiscal Affairs Department, Aging Populations and Public Pension Schemes, 1996, IMF Occasional Paper No. 147 (Washington: International Monetary Fund).

Congressional Budget Office (CBO), 2000, The Long-Term Budget Outlook (Washington).

—_, 2005a, The Long-Term Budget Outlook (Washington).

— 2005b, Quantifying Uncertainty in the Analysis of Long-Term Social Security Projections (Washington).

— 2006, Updated Long-Term Projections for Social Security (Washington).

Conseil d'orientation des retraites, 2006, Troisième rapport du Conseil d'orientation des retraites: perspectives 2020 et 2050 (Paris).

Economic Policy Committee of the European Union (EPC), 2001, Budgetary Challenges Posed by Ageing Populations: The Impact on Public Spending on Pensions, Health and Long-Term Care for the Elderly and Possible Indicators of the Long-Term Sustainability of Public Finances (Brussels).

— 2006, "Impact of Ageing Populations on Public Spending," Report No. ECFIN/CEFCPE(2006)REP/238 (Brussels).

European Commission (EC), 2004, Public Finances in EMU, European Economy No. 3/2004 (Brussels: European Commission). 
— 2006a, The Impact of Ageing on Public Expenditure: Projections for the EU25 Member States on Pensions, Health Care, Long-Term Care, Education and Unemployment Transfers (2004-2050) (Brussels).

— 2006b, Long-term Sustainability of Public Finances in the European Union (Brussels).

Hauner, David, 2006, “Aging—Some Pleasant Fiscal Arithmetic," International Advances in Economic Research (forthcoming).

— Is the "New Economy?" IMF Working Paper No. 112 (Washington: International Monetary Fund).

Heller, Peter S., Richard Hemming, Peter Heller, and a Staff Team from the Fiscal Affairs Department, Aging and Social Expenditure in the Major Industrial Countries, 1986, IMF Occasional Paper No. 47 (Washington: International Monetary Fund).

Heller, Peter S., 2003, Who Will Pay? —Coping with Aging Societies, Climate Change, and Other Long-Term Fiscal Challenges (Washington: International Monetary Fund).

Heller, Peter S., and David Hauner, 2006, "Fiscal Policy in the Face of Long-Term Expenditure Uncertainties," International Tax and Public Finance (Vol. 13), pp. $325-50$.

HM Treasury, 2002, Long-Term Public Finance Report: An Analysis of Fiscal Sustainability (London).

— 2005, Long-Term Public Finance Report: An Analysis of Fiscal Sustainability (London).

—, 2006 , Long-Term Public Finance Report: An Analysis of Fiscal Sustainability (London).

International Monetary Fund, 2004, “Pension Reform Issues in Japan,” in Japan—Selected Issues (Washington).

—_ 2006a, "Germany: A Long-Run Fiscal Scenario Based on Current Policies," in Germany-Selected Issues (Washington).

— 2006b, Italy—Staff Report for the 2006 Article IV Consultation (Washington).

— 2006c, France—Staff Report for the 2006 Article IV Consultation (Washington).

— 2006d, Japan—Staff Report for the 2006 Article IV Consultation (Washington). 
Japanese Ministry of Health, Labor, and Welfare, 2004, Projections for Social Security Benefits and Contributions (Tokyo).

OECD, 2001, "Fiscal Implications of Age-Related Spending," OECD Economics Department Working Paper No. 305 (Paris: Organization for Economic Co-operation and Development).

$\longrightarrow$, 2005, Italy: Economic Survey (Paris: Organization for Economic Co-operation and Development).

— 2006a, "Projecting OECD Health and Long-Term Care Expenditures: What Are the Main Drivers?" Economics Department Working Paper No. 477 (Paris: Organization for Economic Co-operation and Development).

— 2006b, “Assessing Fiscal Risks through Long-Term Budget Projections," Report No. GOV/PGS/SBO(2006)9/FINAL (Paris: Organization for Economic Co-operation and Development).

— , 2006c, "Pension Markets in Focus", Newsletter, Issue 3 (Paris: Organization for Economic Co-operation and Development).

Sefton, J., and Weale, M., 2005, Fiscal Implications of Demographic Uncertainty for the United Kingdom (London: National Institute of Economic and Social Research).

United Nations, 2005, World Population Prospects (New York: United Nations).

Werding, Martin, and Anita Kaltschütz, 2005, "Modellrechnungen zur langfristigen Tragfähigkeit der öffentlichen Finanzen," ifo Beiträge zur Wirtschaftsforschung (Vol. 17). 